\title{
RANCANG BANGUN APLIKASI PERHITUNGAN ALGORITMA APRIORI BERBASIS WEBSITE
}

\author{
Ricki Ardiansyah $^{1 *}$, Maha Rani ${ }^{2}$, Devi Edriani ${ }^{3}$ \\ ${ }^{1}$ Teknik Informatika, Universitas Putra Indonesia "YPTK", Padang \\ ${ }^{2}$ Sistem Informasi, Universitas Putra Indonesia "YPTK", Padang \\ ${ }^{3}$ Akuntansi, Universitas Putra Indonesia "YPTK", Padang \\ Email: "icki.icki76@gmail.com
}

\begin{abstract}
This journal explains how to design and build an application that can perform calculations using apriori algorithm. The workflow applied in this study is a sequential workflow (waterfall method). The application built is a website-based application that can be accessed using a web browser. To make application design in this research, UML modeling is used. The model that has been designed using UML will be implemented into PHP coding which can then be run via a web browser. The supporting tools used are XAMPP which provides apache and mysql services. From the test results, it is found that the application of apriori algorithm based on this website is able to perform calculations using the a priori algorithm accurately. These results are proven by comparing the results obtained from manual calculations with the results of calculations performed by this application using a sample of the same data.
\end{abstract}

Keyword: apriori algorithm; data mining, modeling; mysql; php; uml

\begin{abstract}
Abstrak: Dalam jurnal ini dijelaskan bagaimana merancang hingga membangun sebuah aplikasi yang dapat melakukan perhitungan dengan menggunakan algoritma apriori. Adapun alur kerja yang diterapkan dalam penelitian ini adalah alur kerja yang berurutan (metode waterfall). Aplikasi yang dibangun adalah aplikasi yang berbasis website yang dapat dikases menggunakan web browser. Untuk membuat perancangan aplikasi dalam penelitian ini, digunakan pemodelan UML. Model yang telah dirancang dengan menggunkan UML akan diimplementasikan kedalam koding PHP yang nantinya dapat dijalankan melalui web browser. Adapun tools pendukung yang digunakan adalah XAMPP yang menyediakan service apache dan mysql. Dari hasil pengujian didapatkan bahwa aplikasi perhitungan algoritma apriori berbasis website ini mampu melakukan perhitungan dengan menggunakan algoritma apriori secara akurat. Hasil ini dibuktikan dengan cara membandingkan hasil yang didapat dari perhitungan manual dengan hasil perhitungan yang dilakukan oleh aplikasi ini dengan menggunakan sebuah sampel data yang sama.
\end{abstract}

Kata kunci: algoritma apriori; data mining; mysql; pemodelan; php; uml 
JURTEKSI (Jurnal Teknologi dan Sistem Informasi)

Vol. VII No. 1, Dec 2020, hlm. 61 - 66

DOI: https://doi.org/10.33330/jurteksi.v7i1.945

Available online at http://jurnal.stmikroyal.ac.id/index.php/jurteksi
ISSN 2407-1811 (Print)

ISSN 2550-0201 (Online)

\section{PENDAHULUAN}

Alfaza cosmetic merupakan sebuah toko yang menjual berbagai jenis kosmetik hingga keperluan rumah tangga lainnya. Selama ini pihak toko masih menggunakan cara manual dalam menyusun penempatan barang sehingga pembeli terkadang sulit untuk mencari barang yang biasa dibelinya.

Data mining merupakan suatu proses untuk menggali informasi yang berguna dari data yang besar [1]. Salah satu algoritma yang sering digunakan dalam data mining salah satunya adalah algoritma apriori, hal ini dapat dilihat dari beberapa penelitian yang telah dilakukan sebelumnya [2], [3] terkait data mining. Algoritma Apriori adalah salah satu algoritma yang melakukan pencarian frequent itemset dengan menggunakan teknik association rule [4]. Association rules adalah salah satu task data mining deskriptif yang bertujan untuk menemukan aturan asosiasif antara itemitem data [5].

Tujuan dari penelitian ini adalah membangun sebuah aplikasi yang mampu melakukan mining data yang nantinya menghasilkan informasi yang dapat dipergunakan oleh pihak toko alfaza cosmetik dalam menentukan strategi peletakan barang sesuai kecendrungan pembelian barang dalam satu waktu agar pembeli mudah dalam mencari barang tersebut. Mining data pada bidang penjualan barang seperti yang akan dilakukan di toko alfaza cosmetic sudah pernah dilakukan [6], [7].

Dalam proses perancangan aplikasi yang akan dibangun, peneliti menggunakan diagram UML. Diagram UML sering digunakan dalam membangun aplikasi seperti pada [8], [9]. UML (Unified Modelling Language) adalah sebuah bahasa yang sudah menjadi standar di dunia industri untuk visualisasi, merancang dan mendokumentasikan system piranti lunak. UML menawarkan sebuah standar untuk merancang model sebuah system [10].

\section{METODE}

Metode data mining yang digunakan dalam penelitian ini adalah algoritma apriori yang merupakan salah satu jenis aturan asosiasi yang terdapat dalam data mining. Terdapat 2 tahapan metodologi dasar analisis asosiasi. Tahapan pertama adalah melakukan analisa pola dengan frekuensi tinggi (1).

Support A =

$\frac{\text { Jumlah Transaksi Mengandung A }}{\text { Total Transaksi }}$ X100\%

Untuk mencari nilai support dari 2 item digunakan rumus berikut (2):

Support $(\mathrm{A} n \mathrm{E})=$

Jumlah Transaksi Mengandung AnB $\mathrm{X}$ 100\%

Tahapan kedua adalah membentuk aturan asosiatif (3).

Confidence $=\mathrm{P}(\mathrm{B} \mid \mathrm{A})=$

$\frac{\text { Jumlah Transaksi Mengandung AnB }}{\text { Jumlah Transaksi Mengandung A }}$ X100\%

Nilai lift ratio digunakan sebagai penentu apakah aturan asosiasi yang terbentuk valid atau tidak valid. Untuk 
JURTEKSI (Jurnal Teknologi dan Sistem Informasi)

Vol. VII No. 1, Dec 2020, hlm. 61 - 66

DOI: https://doi.org/10.33330/jurteksi.v7i1.945

Available online at http://jurnal.stmikroyal.ac.id/index.php/jurteksi
ISSN 2407-1811 (Print)

ISSN 2550-0201 (Online) mendapatkan nilai lift ratio, rumus yang digunakan adalah sebagai berikut (4):

Lift ratio

$$
=\frac{\text { Confidence }(\mathrm{A}, \mathrm{B})}{\text { Benchmark Confidence }(\mathrm{A}, \mathrm{B})}
$$

Aplikasi perhitungan apriori ini nantinya akan digunakan oleh pihak toko alfaza cosmetic untuk mendukung pihak toko meningkatkan penjualan serta menyusun strategi penempatan barang.

\section{HASIL DAN PEMBAHASAN}

Data sampel yang akan digunakan dalam perhitungan manual dan pengujian aplikasi dapat dilihat pada tabel 1 .

Dari perhitungan manual yang dilakukan, hasilnya dapat dilihat pada tabel 2 .
Setelah dilakukan perhitungan manual menggunakan algortima apriori dengan menggunakan data sampel, selanjutnya dilakukan perancangan model UML untuk membangun aplikasi perhitungan algortima apriori. Diagram UML yang digunakan antara lain adalah diagram usecase dan diagram kelas.

Rancangan diagram usecase dilakukan untuk mengetahui berbagai fungsi yang dapat digunakan oleh pengguna dari aplikasi perhitungan algoritma apriori. Sedangkan Pada diagram kelas akan di tampilkan strukturstruktur sistem dari sudut pendefinisian untuk setiap kelas yang digunakan dalam membangun sistem.

Tabel 1. Tabel Data Sampel

\begin{tabular}{ccc}
\hline ID & Tanggal & Item \\
\hline 1 & $28 / 09 / 2020$ & sabun, pensil,gunting, buku, pena \\
\hline 2 & $29 / 09 / 2020$ & buku, pensil, penggaris, buku \\
\hline 3 & $30 / 09 / 2020$ & gunting, sabun, penggaris, pensil \\
\hline 4 & $30 / 09 / 2020$ & sabun, pensil, gunting \\
\hline 5 & $30 / 09 / 2020$ & sabun, pensil, buku \\
\hline 6 & $30 / 09 / 2020$ & gunting, buku, pena \\
\hline
\end{tabular}

Tabel 2. Hasil Perhitungan Manual

\begin{tabular}{rlrrl}
\hline No & \multicolumn{1}{c}{ X => Y } & Confidence & $\begin{array}{c}\text { Nilai } \\
\text { Uji lift }\end{array}$ & Korelasi rule \\
\hline 1 & Sabun , Pensil => Gunting & 75 & 0,9 & korelasi negatif \\
\hline 2 & Pensil , Gunting => Sabun & 75 & 1,13 & korelasi positif \\
\hline 3 & Gunting, Sabun => Pensil & 100 & 1,2 & korelasi positif \\
\hline 4 & Sabun => Gunting, Pensil & 75 & 1,13 & korelasi positif \\
\hline 5 & Pensil => Sabun , Gunting & 60 & 1,2 & korelasi positif \\
\hline 6 & Gunting => Pensil , Sabun & 60 & 0,9 & korelasi negatif \\
\hline 7 & Dst & dst & dst & dst \\
\hline
\end{tabular}


JURTEKSI (Jurnal Teknologi dan Sistem Informasi)

Vol. VII No. 1, Dec 2020, hlm. 61 - 66

DOI: https://doi.org/10.33330/jurteksi.v7i1.945

Available online at http://jurnal.stmikroyal.ac.id/index.php/jurteksi
ISSN 2407-1811 (Print)

ISSN 2550-0201 (Online)
Untuk rancangan diagram usecase dapat dilihat pada gambar 1. Pada gambar 1 menunjukkan bahwa untuk mengakses fungsi-fungsi yang ada pada aplikasi, user diharuskan untuk login terlebih dahulu. Setelah itu user dapat menggunakan menu yang disediakan oleh aplikasi seperti memasukkan data transaksi, melakukan proses mining dan melihat hasil mining. Dalam proses mining nantinya seorang user hanya dapat mengakses satu data itemset1, itemset2, itemset3 dan confidence berdasarkan id_process. Pada aplikasi ini juga dapat dilihat hasil dari mining yang telah dilakukan yang digambarkan dengan hubungan antara kelas user dan process_log. Seorang user dapat mengakses banyak data yang ada dalam process_log.

Setelah rancangan yang dibangun menggunakan pemodelan UML, maka tahap selanjutnya adalah mengimplementasikan model diagram UML yang telah dibuat kedalam bahasa pemrograman PHP.

Aplikasi yang telah jadi, dapat diuji dengan menggunakan data sampel yang digunakan dalam pengujian manual.

Berdasarkan rule association yang telah diperoleh dari perhitungan manual dan perhitungan menggunakan aplikasi, maka dihasilkan rule yang dapat dilihat pada tabel 3.

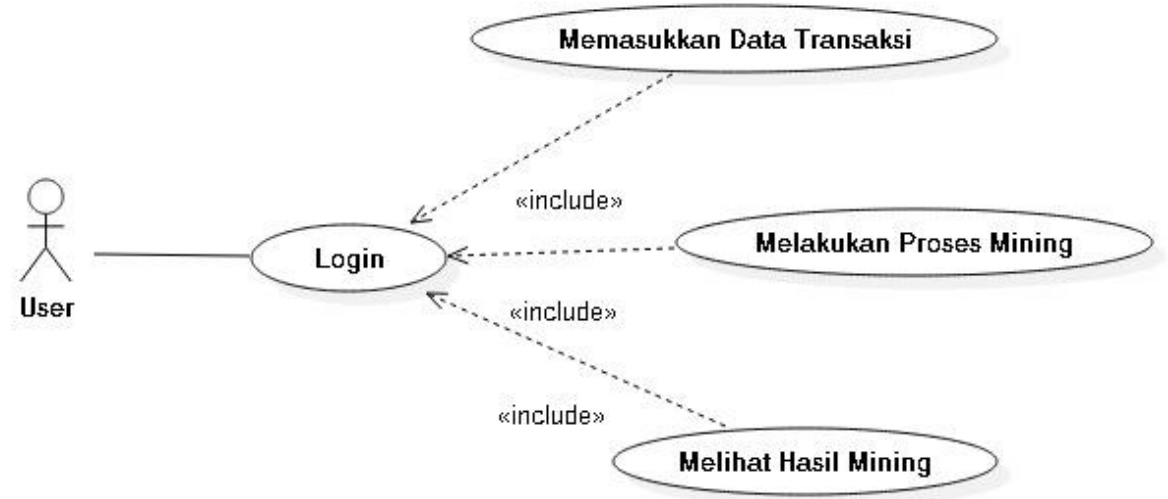

Gambar 1. Rancangan Diagram Usecase Aplikasi Perhitungan Algoritma Apriori 
JURTEKSI (Jurnal Teknologi dan Sistem Informasi)

Vol. VII No. 1, Dec 2020, hlm. 61 - 66

DOI: https://doi.org/10.33330/jurteksi.v7i1.945

Available online at http://jurnal.stmikroyal.ac.id/index.php/jurteksi
ISSN 2407-1811 (Print)

ISSN 2550-0201 (Online)

Tabel 3. Tabel Rule Asosiasi

\begin{tabular}{cl}
\hline \multicolumn{2}{l}{ No. } \\
\hline 1 & (IF) konsumen membeli Sabun dan Pensil, (Then) konsumen juga akan membeli Gunting \\
\hline 2 & (IF) konsumen membeli Pensil dan Gunting, (Then) konsumen juga akan membeli Sabun \\
\hline 3 & (IF) konsumen membeli Gunting dan Sabun, (Then) konsumen juga akan membeli Pensil \\
\hline 4 & (IF) konsumen membeli Sabun, (Then) konsumen juga akan membeli Gunting, Pensil \\
\hline 5 & (IF) konsumen membeli Pensil, (Then) konsumen juga akan membeli Sabun, Gunting \\
\hline 6 & (IF) konsumen membeli Gunting, (Then) konsumen juga akan membeli Pensil, Sabun \\
\hline 7 & (IF) konsumen membeli Sabun, (Then) konsumen juga akan membeli Pensil \\
\hline 8 & (IF) konsumen membeli Pensil, (Then) konsumen juga akan membeli Sabun \\
\hline 9 & (IF) konsumen membeli Sabun, (Then) konsumen juga akan membeli Gunting \\
\hline 10 & (IF) konsumen membeli Gunting, (Then) konsumen juga akan membeli Sabun \\
\hline 11 & (IF) konsumen membeli Pensil, (Then) konsumen juga akan membeli Gunting \\
\hline 12 & (IF) konsumen membeli Gunting, (Then) konsumen juga akan membeli Pensil \\
\hline 13 & (IF) konsumen membeli Pensil, (Then) konsumen juga akan membeli Buku \\
\hline 14 & (IF) konsumen membeli Buku, (Then) konsumen juga akan membeli Pensil \\
\hline 15 & (IF) konsumen membeli Gunting, (Then) konsumen juga akan membeli Buku \\
\hline 16 & (IF) konsumen membeli Buku, (Then) konsumen juga akan membeli Gunting \\
\hline
\end{tabular}

\section{SIMPULAN}

Berdasarkan analisa, perancangan serta pengujian yang telah dilakukan, maka dapat ditarik kesimpulan bahwa pemodelan UML dapat diaplikasikan dengan baik dalam membangun Aplikasi Perhitungan Algoritma Apriori Berbasis Web dan aplikasi yang telah dibangun mampu menghasilkan perhitungan serta pembentukan rule association dengan nilai yang sama dengan hasil perhitungan dan pembentukan rule association yang dilakukan secara manual. Diharapkan aplikasi ini dapat mendukung pihak toko alfaza cosmetic dalam menentukan strategi penjualan hingga peletakan barang pada toko alfaza cosmetic.

\section{DAFTAR PUSTAKA}

[1] A. W. Wijayanti, "Analisis Hasil Implementasi Data Mining Menggunakan Algoritma Apriori pada Apotek," J. Edukasi dan Penelit. Inform., 2017, doi: 10.26418/jp.v3i1.19534.

[2] M. P. Tana, F. Marisa, and I. D. Wijaya, "Penerapan Metode Data Mining Market Basket Analysis Terhadap Data Penjualan Produk Pada Toko Oase Menggunakan Algoritma Apriori," J I M P - J. Inform. Merdeka Pasuruan, 2018, doi: 10.37438/jimp.v3i2.167.

[3] F. Rahmawati and N. Merlina, "Metode Data Mining Terhadap Data Penjualan Sparepart Mesin Fotocopy Menggunakan Algoritma Apriori," PIKSEL Penelit. Ilmu Komput. Sist. Embed. Log., 2018, 
doi: 10.33558/piksel.v6i1.1390.

[4] S. Sinaga and A. M. Husein, "Penerapan Algoritma Apriori dalam Data Mining untuk Memprediksi Pola Pengunjung pada Objek Wisata Kabupaten Karo," J. Teknol. dan Ilmu Komput. Prima, 2019, doi: 10.34012/jutikomp.v2i1.461.

[5] W. Aprianti, K. A. Hafizd, and M. R. Rizani, "Implementasi Association Rules dengan Algoritma Apriori pada Dataset Kemiskinan," Limits J. Math. Its Appl., 2017, doi: 10.12962/limits.v14i2.2933.

[6] N. Adha, L. T. Sianturi, and E. R. Siagian, "IMPLEMENTASI DATA MINING PENJUALAN SABUN DENGAN MENGGUNAKAN METODE APRIORI ( Studi Kasus: PT. Unilever)," Maj. Ilm. INTI, 2017.

[7] A. R. Riszky and M. Sadikin, "Data Mining Menggunakan Algoritma Apriori untuk Rekomendasi Produk bagi Pelanggan," J. Teknol. dan Sist. Komput., 2019, doi: 10.14710/jtsiskom.7.3.2019.103108.

[8] D. Zaliluddin and R. Rohmat, "PERANCANGAN SISTEM INFORMASI PENJUALAN BERBASIS WEB (STUDI KASUS PADA NEWBIESTORE)," Infotech $J$., 2018.

[9] D. Wira, T. Putra, and R. Andriani, "Unified Modelling Language ( UML ) dalam Perancangan Sistem Informasi Permohonan Pembayaran Restitusi SPPD," vol.
7, no. 1, 2019.

[10] S. Pohan, "PEMODELAN UML UNTUK MENENTUKAN KELULUSAN PENERIMAAN SISWA BARU BERBASIS WEB," J. Inform., 2019, doi: 10.36987/informatika.v3i2.214. 